\title{
Peertechz
}

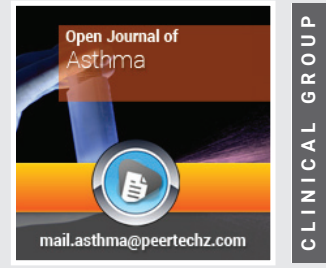

\section{Barriers and solutions to stepping down asthma}

\section{treatment}

\section{Nguyen-Ho Lam*}

Department of Internal Medicine, University of Medicine and Pharmacy at Ho Chi Minh City, Vietnam

Received: 06 August, 2020

Accepted: 18 August, 2020

Published: 19 August, 2020

*Corresponding author: Nguyen-Ho Lam, Department of Internal Medicine, University of Medicine and Pharmacy, Ho Chi Minh City, Vietnam,

Email: bsholam1986@gmail.com; nguyenholam@ump.edu.vn

https://www. peertechz.com

Check for updates
Asthma is a chronic airway disease with two characteristic features: (1) chronic airway inflammation (the most common eosinophilic airway inflammation) and (2) airway hyperresponsiveness (excessive airway constriction by normal triggers) [1]. Management of asthma requires long-term treatment to achieve well-controlled symptoms and prevent the risk of exacerbation in future. Inhaled corticosteroid (ICS) is the mainstay therapy of asthma with strong evidences [2]. Nonetheless it is still the existence of gap in knowledge "what is the most appropriate dose of ICS to treat asthmatic patient?". Beside physicians are always concerned about unnecessary side effects of long-term treatment with ICS, especially high dose, including osteoporosis, cataracts, chronic adrenal insufficiency, thinning skin and bruise, risk of pneumonia and diabetes mellitus [2]. Therefore almost national and international guidelines recommend the stepwise treatment in management of asthma (reducing ICS dose consistently 25$50 \%$ when asthmatic patients achieved well-controlled at least three months) to approach the lowest effective ICS dose and the lowest risk of side effects [3-5]. However, stepping down asthma treatment in real world is still limited. The study at England revealed that the low proportion of asthmatic patients (6\%) was stepped down although $62 \%$ of them was wellcontrolled during one-year [6]. We need to analyze the benefits of the step-down strategy and barriers in clinical practice to apply it more effectively.

\section{Benefits from stepping down strategy of inhaled corti- costeroid dose}

Guidelines encourage the rapid acquirement of wellcontrolled asthma with the initial treatment without specific recommendations of initial ICS dose appropriately in association of both efficiency and safety [5]. It results in overtreatment at initial ICS dose and risk of systemic side effects. With stepping down strategy, we can resolve the over-treatment to reach the minimum effective ICS dose $[3,4,7]$. Moreover the results of published studies showed additional benefits with stepping down strategy including (1) higher proportion of therapeutic adherence in asthmatic patients $[3,4],(2)$ decreasing burden of therapeutic costs [8] and (3) reviewing the definite diagnosis of asthma [9]. Bruce G. Bender identified many barriers of treatment influencing the asthmatic patient's compliance (prolonged or prophylactic therapy, delayed effects, expense, adverse side and complex regimen) [10]. Asthmatic patients are enough perception to understand the association between severity of asthma and complexity of therapeutic regimen. Therefore in case well-controlled asthma, patients could refuse complex regimen which they believe it unnecessary. The stepping down treatment is essential in securing therapeutic adherence. Moreover in patients with mild asthma, when stopping asthma medications completely, there is no symptomatic worsening, no presence of airway obstruction, or no increasing the level of FeNO , they may have no asthma really [9].

\section{Barriers to stepping down strategy of inhaled corticos- teroid dose}

Risks when reducing asthma medications: Although the stepping down treatment through published studies showed safety (no harm to efficiency of treatment) [11], its failure risk (loss of control and development of exacerbation) should be noticed. E. Martínez-Moragón, et al. (2020) revealed the high rate of failure in stepping down treatment $41.7 \%$, associated with several factors such as higher age, initial severity of asthma, and shortening duration of well-controlled asthma before stepping down [12]. Hence asthmatic patients could be stepped down successfully if the investigation of risk factors is undertaken comprehensively. Asthma guidelines usually recommend the stepping down treatment when achieving well-controlled at least three months[5]. However, the study 
of Omar S. Usmani, et al. (2017) showed that the history of exacerbation during previous 12 months was a significant predictor of occurring exacerbation when stepping down [13]. In 2019 Luis Pérez de Llano, et al. developed a simple score for future risk prediction in asthmatic patients undergoing step-down strategy which included four factors (FEV1/ FVC $<0.7$, current FEV1 $<80 \%, \geq 1$ episode of exacerbation during previous one year, and ACT score < 25) [14]. Recently the measurement of FeNO, an useful biomarker for guiding management of asthma and evaluating the control of asthma [15], have been suggested as a biomarker guiding for stepping down in mild to moderate well-controlled asthma [1,16]. All together support to be over the failure risk when undergoing stepping down strategy. An additional concern about longterm efficiency of stepping-down strategy, Matthew A Rank, et al. (2015) reported the rate of $32 \%$ asthmatic patients with exacerbation during two years on stepped-down therapy [17]. However it is difficult to conclude the correlation between exacerbation and step-down therapy because this study had no control group. Further research need be undertaken to answer the long-term efficiency of this strategy.

\section{Heterogeneity of step-down strategies}

There are many steps of control asthma suitable with the severity of individual asthmatic patients such as ICS monotherapy, leukotriene receptor antagonist, combination of ICS and Long-Acting Beta-Agonist (LABA) (early onset of bronchodilator action or not), or combination of ICS-LABA and long-acting muscarinic receptor antagonist [5]. To every specific step treatment, it will be a step-down strategy respectively. However there is no consensus to guide physicians reduce asthma treatment. For instance the step-down strategy from treatment with combination ICS-LABA, whether withdrawal LABA or reducing ICS dose should be undertaken firstly, it is more favorable to reduce ICS dose suggested via the majority of asthma guidelines. Particularly in patients with mild asthma or well-controlled with step 2 treatment, there are several stepping down options (reducing ICS dose to lowest dose, switching regimen of scheduled ICS to regimen of "as needed" ICS when using SABA) but what optimal option is obscured [9]. The study of Michael R. Gionfriddo, et al. 2015 showed insufficient evidence to switch scheduled to "as needed" [18]. Although the results of SYGMA-1 and SYGMA-2 studies supported more evidence to "as needed" strategy $[19,20]$, , further study in real world is necessary because this strategy will depend on the patient's asthma perception.

\section{Barriers from physician's perception}

"Patients are well controlled with current treatment, why I need to change the regimen?". Although aforementioned evidences of benefit, the minority of physician would refuse the stepping down strategy [21]. The study of Deirdre Siddaway (2018) revealed that the primary care staff were lack of knowledge and confident in stepping down asthma treatment [22]. In England only small proportion (6\%) of asthmatic patients were stepped down during one year follow-up, although the rate of well-controlled asthma was $62 \%$ in the same year [6].

\section{Characteristics of asthmatic patients}

Personalized therapy has an important role in management of asthma. Pathogenesis of eosinophilic airway inflammation is common in asthmatic patients and responsive to ICS treatment. In another hand several asthmatic patient with non-eosinophilic inflammation, reduction of ICS dose also showed successfully in two-thirds of these subjects (the study of S. Demarche, et al. 2018) [23]. Moreover, differences in race/ ethnicity could influence the effect of asthma medications [24]. For instance with the same of severity of stabilize asthma, it will be well-controlled with low ICS dose but another patient will require higher ICS dose to control. This feature also affects to the efficiency of stepping-down strategy. In clinical practice, few asthmatic patients even refuse reducing ICS dose because they worries their symptoms worsening [22]. It is very important to communicate with patient about stepping down strategy completely and have specific action plan when stepping down [25].

\section{Recommendation and solutions to step down asthma treatment}

With more published studies, stepping down asthma treatment could be undertaken more effectively with the low risk of both loss of control asthma and development of exacerbation. Physicians should consider stepping down asthma medications when asthmatic patients are well controlled and normal pulmonary function. The evaluation of risk factors of failure, calculating the score of future prediction and measuring FeNO are essential to secure success of the stepping down strategy. Besides the complete communication between physician and asthmatic patient about benefits of stepping down strategy, specific action plan to deal with loss of asthma control when reducing ICS dose, and scheduled appointments to check is pivotal factor to enhance patient's adherence to this strategy.

\section{References}

1. Wang K, Verbakel JY, Oke J, Fleming-Nouri A, Brewin J, et al. (2020) Using fractional exhaled nitric oxide to guide step-down treatment decisions in patients with asthma: a systematic review and individual patient data metaanalysis. Eur Respir J 55: 1902150. Link: https://bit.ly/315d2Tx

2. Chipps B, Taylor B, Bayer V, Shaikh A, Mosnaim G, et al. (2020) Relative efficacy and safety of inhaled corticosteroids in patients with asthma: Systematic review and network meta-analysis. Ann Allergy Asthma Immunol 125: 163170.e3. Link: https://bit.ly/326LZXi

3. Rank MA, Peters SP (2014) The risks, benefits, and uncertainties of stepping down asthma medications. J Allergy Clin Immunol Pract 2: 503-509. Link: https://bit.ly/2DTWK7v

4. Bacharier LB (2002) "Step-down" therapy for asthma: why, when, and how? J Allergy Clin Immunol 109: 916-919. Link: https://bit.ly/3iJAOuu

5. Global Initiative for Asthma. Global strategy for asthma management and prevention 2018 Link: https://bit.ly/325jSaT

6. Bloom C, Quint J (2019) How common is stepping-down asthma treatment in England? Eur Respir J 54: PA2569. Link: https://bit.ly/2E2Z1x8

7. O'Byrne PM, Reddel HK, Colice GL (2010) Does the current stepwise approach to asthma pharmacotherapy encourage over-treatment? Respirology 15: 596602. Link: https://bit.ly/3iSrqF2 
8. Rank MA, Liesinger JT, Branda ME, Gionfriddo MR, Schatz M, et al. (2016) Comparative safety and costs of stepping down asthma medications in patients with controlled asthma. J Allergy Clin Immunol 137: 1373-1379. Link: https://bit.ly/2Eak2pt

9. Chipps BE, Bacharier LB, Murphy KR, Lang D, Farrar JR, et al. (2019) The asthma controller step-down yardstick. Ann Allergy Asthma Immunol 122 241-262. Link: https://bit.ly/3aCapM5

10. Bender BG (2002) Overcoming barriers to nonadherence in asthma treatment. Journal of Allergy and Clinical Immunology 109: S554- S559. Link: https://bit.ly/2DTXGc1

11. Crossingham I, Evans DJ, Halcovitch NR, Marsden PA (2017) Stepping down the dose of inhaled corticosteroids for adults with asthma. Cochrane Database Syst Rev 2: Cd011802. Link: https://bit.ly/3kUWBRE

12. Martínez-Moragóna E, Delgadob J, Mogrovejoa S, Fernández-Sánchezc T (2020) On behalf of the grupo de investigación STEP. Factors that determine the loss of control when reducing therapy by steps in the treatment of moderate-severe asthma in standard clinical practice: A multicentre Spanish study. Rev Clin Esp 220: 86-93. Link: https://bit.ly/3aAkrNP

13. Usmani OS, Kemppinen A, Gardener E, Thomas V, Konduru PR, et al. (2017) A randomized pragmatic trial of changing to and stepping down fluticasone/ formoterol in asthma. J Allergy Clin Immunol Pract 5: 1378-1387. Link: https://bit.ly/3h7Ghe1

14. Llano LPd, García-Rivero JL, Urrutia I, Martínez-Moragón E, Ramos J, et al. (2019) A Simple Score for Future Risk Prediction in Patients with Controlled Asthma Who Undergo a Guidelines-Based Step-Down Strategy. J Allergy Clin Immunol Pract 7: 1214-1221.e3. Link: https://bit.ly/2Edru2W

15. de-Abreu FC, da-Silva JLR, Rabahi MF (2019) The fraction exhaled nitric oxide as a biomarker of asthma control. Biomark Insights 14: 1177271919826550. Link: https://bit.ly/2E8mvR7

16. Dinh-Xuan AT, Brusselle G (2020) FENO as a biomarker guide for inhaled corticosteroid step down in patients with mild-to-moderate well-controlled asthma. Eur Respir J 55: 2001319. Link: https://bit.ly/3g9rFK3
17. Rank MA, Johnson R, Branda M, Herrin J, van-Houten H, et al. (2015) Long term Outcomes After Stepping Down Asthma Controller Medications: A Claims-Based, Time-to-Event Analysis. Chest 148: 630-639. Link: https://bit.ly/3kVTWaE

18. Gionfriddo MR, Hagan JB, Hagan CR, Volcheck GW, Castaneda-Guarderas A, et al. (2015) Stepping down inhaled corticosteroids from scheduled to as needed in stable asthma: Systematic review and meta-analysis. Allergy Asthma Proc 36: 262-267. Link: https://bit.ly/3iPVxwx

19. Bateman ED, Reddel HK, O’Byrne PM, Barnes PJ, Zhong N, et al. (2018) Asneeded budesonide-formoterol versus maintenance budesonide in mild asthma. N Engl J Med 378: 1877-1887. Link: https://bit.ly/3hb8DEc

20. O’Byrne PM, FitzGerald JM, Bateman ED, Barnes PJ, Zhong N, et al. (2018) Inhaled combined budesonide-formoterol as needed in mild asthma. $\mathrm{N}$ Engl $\mathrm{J}$ Med 378: 1865-1876. Link: https://bit.ly/34505cK

21. Bloom Cl, Preux Ld, Sheikh A, Quint JK (2020) Health and cost impact of stepping down asthmamedication for UK patients, 2001-2017: A population-based observational study. PLoS Med 17: e1003145. Link: https://bit.ly/31X8jmg

22. Siddaway D (2018) Stepping down asthma treatment: perceptions of primary care staff. Nursing Times 114: 18-21. Link: https://bit.ly/31VNNSQ

23. Demarche S, Schleich F, Henket M, Paulus V, Louis R, et al. (2018) Step-down of inhaled corticosteroids in non-eosinophilic asthma: A prospective trial in real life. Clin Exp Allergy 48: 525-535. Link: https://bit.ly/2FDCRIH

24. Cazzola M, Calzetta L, Matera MG, Hanania NA, Rogliani P (2018) How does race/ethnicity influence pharmacological response to asthma therapies? Expert Opinion on Drug Metabolism \& Toxicology 14: 435-446. Link: https://bit.ly/2E6dVCF

25. Lipworth B, Israel E (2018) Asthma Step-Down Strategies: Perhaps the Patient Should Decide? J Allergy Clin Immunol Pract 6: 644-645. Link: https://bit.ly/2EbhBmo
Discover a bigger Impact and Visibility of your article publication with Peertechz Publications

Copyright: (c) 2020 Lam NH. This is an open-access article distributed under the terms of the Creative Commons Attribution License, which permits unrestricted use distribution, and reproduction in any medium, provided the original author and source are credited. 